\title{
Antibiotic prescribing: the need for a policy in general practice
}

\author{
Tim D Wyatt, Clare M Passmore, Norman C Morrow, Philip M Reilly
}

\begin{abstract}
Objective-To see whether changes in prescribing of oral antibacterials in Northern Ireland show the need for a community antibiotics policy.

Design-Analysis of prescribing totals for several oral antibiotics obtained retrospectively from the prescription pricing bureau for the years 1983-7.

Setting-Audit of anti-infective prescribing in general practice in Northern Ireland over five years.

Main outcome measure-Respective usage of agents defined as "common" and "occasional" in 1983.

Results-There was a gradual decrease in the relative use of common agents from $82 \%$ of the total in 1983 to $77 \%$ in 1987 together with a complementary increase in the use of occasional agents from $5 \%$ to $10 \%$. Pronounced changes were noted in the use of amoxycillin, ampicillin, erythromycin, minocycline, doxycycline, and amoxycillin-clavulanic acid.

Conclusion-Though this survey found reasonably conservative prescribing, the trend towards increased use of occasional agents has both clinical and cost implications which could be addressed by the use of a prescribing formulary.
\end{abstract}

\section{Introduction}

It has been claimed that antibiotics are used indiscriminately, ${ }^{1-3}$ are prescribed for problems for which they are ineffective, ${ }^{4-6}$ and are promoted in a way that may create unrealistic expectations for both the consumer and the prescriber.

In hospital practice the need for an antibiotic prescribing policy is well established and policies exist in many hospitals. ${ }^{78}$ Policies generally offer guidance ranging from those antibiotics which may be freely prescribed to those which are subject to varying degrees of restriction, and from rigid written policies to those promulgated informally by word of mouth. Their function is to encourage the safe, effective, rational, and economic use of antibiotics.

Two major developments in particular have indicated a need for an antibiotic prescribing policy in general practice. Firstly, there are an increasing number and variety of antibiotics being produced which often have no clear cut clinical advantage over those already available. In addition, potent broad spectrum antibiotics initially directed towards hospital use - for example, the quinolones-are now available in oral form and are being promoted for use in the community. Secondly, with increasing financial pressure on the health service the value of a drug must be assessed against its competitors by price as well as by its clinical efficacy. Thus a shift towards generic prescribing must be considered.

A further reason for establishing an effective antibiotic policy in general practice is to limit the emergence of resistant organisms resulting from the selection pressure exerted by the type and, more importantly, amount of a particular agent used. In Northern Ireland in 1976 the emergence and subsequent spread of gentamicin resistant Staphylococcus aureus was clearly associated with the excessive use in dermatological unit of a topical preparation containing the antibiotic. ${ }^{9}$ By using normal control of infection measures the outbreak in the unit was brought under control but, because of the considerable usage by general practitioners ( 117528 units of $15 \mathrm{~g}$ prescribed in a typical four month period), carriage of the organism was encouraged outside hospital. ${ }^{10}$ Amyes $^{11}$ and the Consumer's Association ${ }^{12}$ suggested that general practitioners were to blame for the increasing incidence of bacterial resistance in the community as they prescribed most of the antibiotics. In Northern Ireland, however, the increase in resistance to the commonly used antibiotics in this setting does not seem to have been great (J G Barr, personal communication, 1989).

Before deciding the need for or nature of a policy several questions must be considered - for example, What are the prescribing trends? What antimicrobials are being used most frequently? What has been the impact of new compounds and presentations? Does antibiotic resistance occurring in the community warrant the need for these new agents? and What potential exists for cost savings without the impairment of clinical efficacy? To examine these issues an audit of anti-infective prescribing in general practice in Northern Ireland over five years was carried out.

\section{Materials and methods}

The prescription pricing bureau of the Central Services Agency in Northern Ireland, largely equivalent to the family practitioner committees in England and Wales, records the number of health service prescriptions and the number of doses of each agent dispensed by pharmacists and dispensing doctors.

Central Services Agency records were analysed from 1983 to 1987 inclusive and the total annual numbers of prescriptions and dosing units of antimicrobial agents prescribed were obtained. In order to compare and compute total quantities across the range of presentations of a particular compound a standard dosing unit based on the single recommended adult dose for that agent was used..$^{13}$

The agents studied were assigned to a "common" or "occasional" category based on their usage in 1983. Antimicrobials whose individual usage did not exceed $2 \%$ of the total were defined as occasional. All others studied were defined as common.

More detailed monthly totals were obtained for pivampicillin and ciprofloxacin to investigate the changes occurring at specific times in their commercial history. The usage of pivampicillin was surveyed monthly for 15 months after its launch in 1982 and again four years later. Prescriptions of ciprofloxacin 
were monitored for the first 18 months after its launch in 1987.

\section{Results}

The annual number of prescriptions for antimicrobials remained fairly constant over the five years (fig 1). The number of dosing units of common agents (fig 2) and occasional agents (fig 3 ) showed a direct correlation with the numbers of prescriptions written $(r=0.996$ and 0.994 respectively). Over the five years the two

FIG 1-Annual number and cost of prescriptions for anti-infective agents between 1983 and 1987
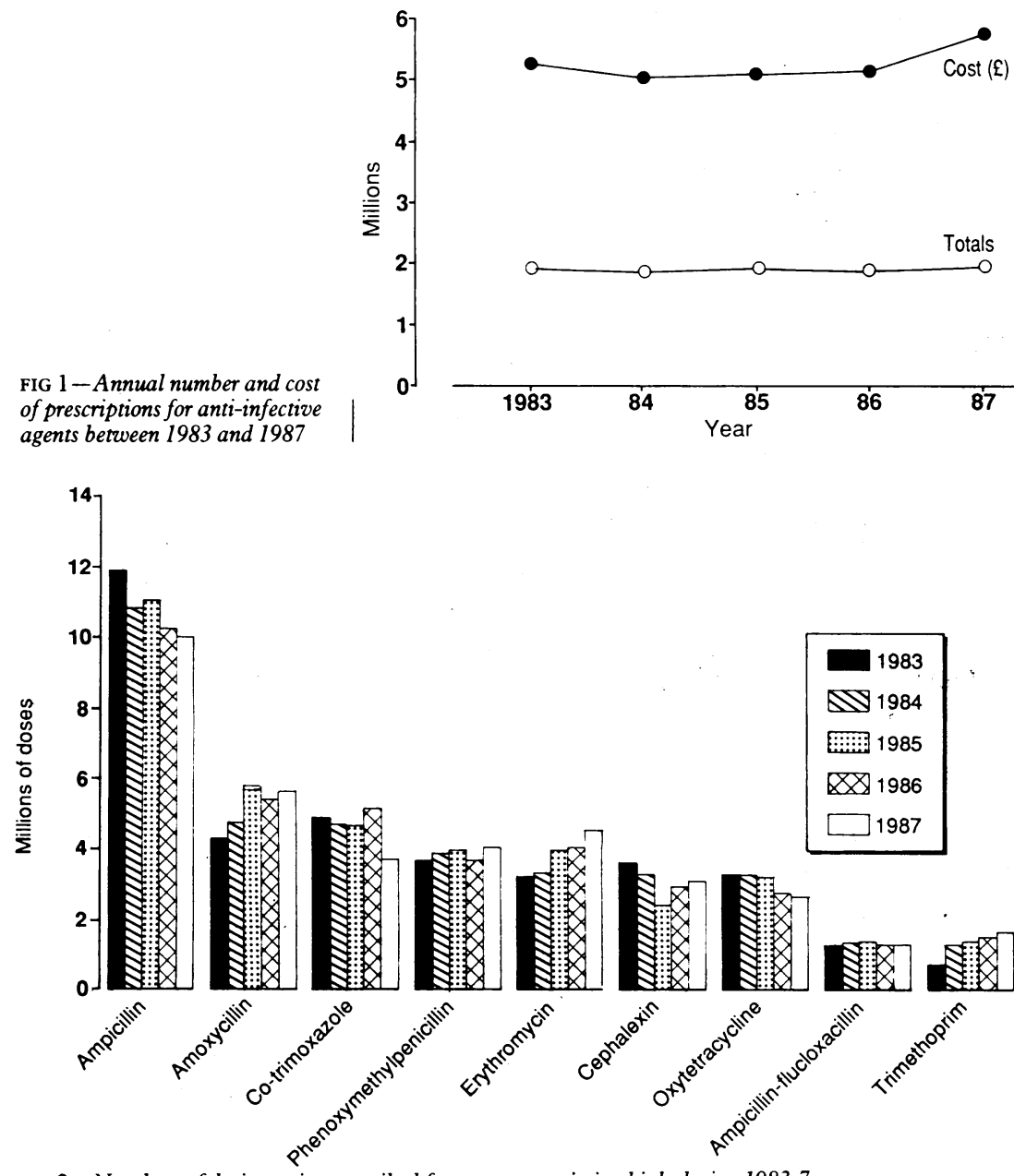

FIG 2-Numbers of dosing units prescribed for common antimicrobials during 1983-7

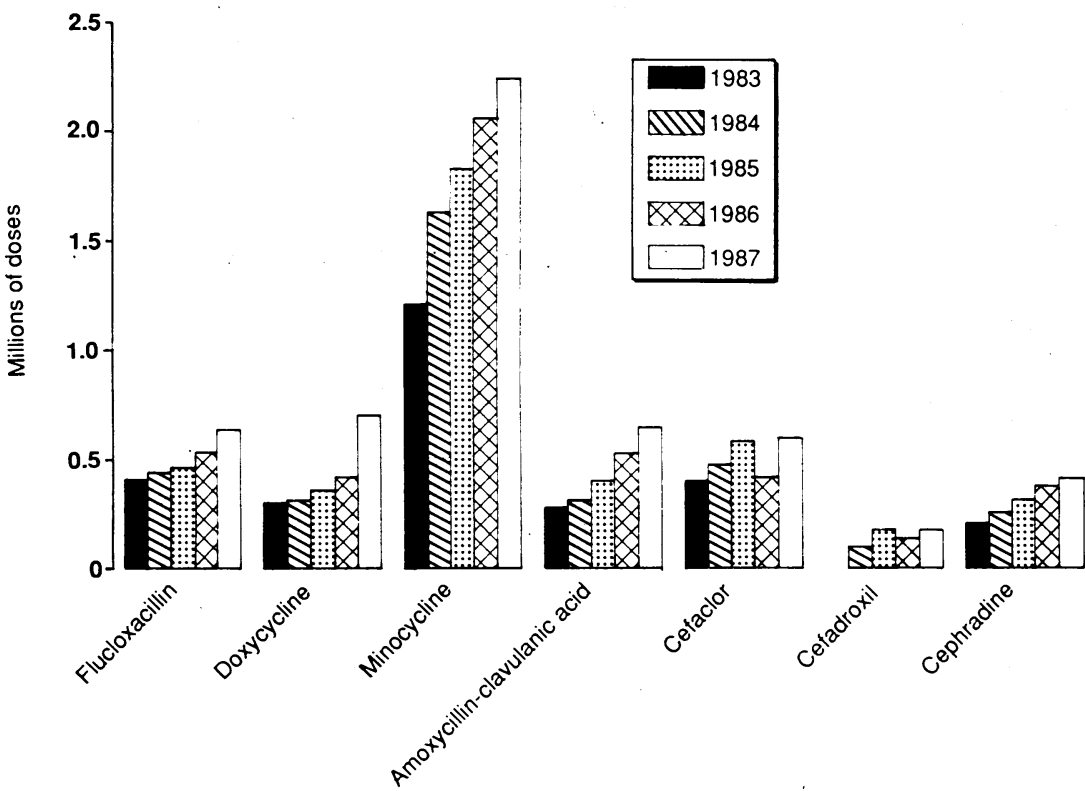

FIG 3-Numbers of dosing units prescribed for occasional antimicrobials during 1983-7
Cost of a day's treatment with "common" and "occasional" agents

\begin{tabular}{|c|c|c|c|c|}
\hline \multirow[b]{2}{*}{ Agent } & \multirow{2}{*}{$\begin{array}{c}\text { Dosing } \\
\text { unit (mg) }\end{array}$} & \multirow{2}{*}{$\begin{array}{c}\text { No of } \\
\text { daily doses }\end{array}$} & \multicolumn{2}{|c|}{$\operatorname{Cost}(\mathfrak{£})$} \\
\hline & & & Generic & Proprietary \\
\hline \multicolumn{5}{|l|}{ Common: } \\
\hline Oxytetracycline & 250 & 4 & 0.05 & $0 \cdot 12$ \\
\hline Trimethoprim & 100 & 4 & $0 \cdot 12$ & $0 \cdot 19$ \\
\hline Ampicillin & 250 & 4 & 0.13 & 0.28 \\
\hline Erythromycin & 250 & 4 & 0.17 & 0.45 \\
\hline Co-trimoxazole & 480 & 4 & 0.33 & 0.45 \\
\hline Cephalexin & 250 & 4 & - & 0.47 \\
\hline Amoxycillin & 250 & 3 & 0.47 & 0.51 \\
\hline Ampicillin/flucloxacillin & 500 & 4 & - & 0.85 \\
\hline \multicolumn{5}{|l|}{ Occasional: } \\
\hline Pivampicillin & 500 & 2 & - & 0.44 \\
\hline Doxycycline & 100 & $i$ & 0.47 & 0.51 \\
\hline Minocycline & 50 & 2 & - & 0.53 \\
\hline Cefadroxil & 500 & 2 & - & 0.60 \\
\hline Cephradine & 250 & 4 & - & 0.68 \\
\hline Flucloxacillin & 250 & 4 & 0.54 & 0.80 \\
\hline \multicolumn{5}{|l|}{ Amoxycillin-clavulanic } \\
\hline acid & 375 & 3 & - & 0.87 \\
\hline Cefaclor & 250 & 3 & - & $1 \cdot 12$ \\
\hline Ciprofloxacin & 250 & 2 & - & 1.50 \\
\hline Cefuroxime axetil & 250 & 2 & - & 1.80 \\
\hline
\end{tabular}

groups represented $87 \%$ of all antimicrobial agents prescribed. The remaining $13 \%$, not included in the study, comprised antifungals, antiviral agents, anthelmintic preparations, and antibacterials such as antituberculous drugs, metronidazole, and nitrofurantoin used for specialised infections.

Between 1983 and 1987 there was a decline in the amount of the common agents used from $82 \%$ to $77 \%$ of the total. This was paralleled by an increase in the occasional agents prescribed from $5 \%$ to $10 \%$. Changes in the usage of some individual agents since 1983 (that year being used as baseline; fig 4) showed a notable increase in the use of amoxycillin, erythromycin, and trimethoprim among the common agents and all of the occasional compounds. In contrast there was a decrease in the use of ampicillin and co-trimoxazole. Several other agents within the occasional group are not represented in figure 3 owing to very low levels of usage-for example, talampicillin and pivampicillin. When examining the usage of these agents, however, we found an erratic prescribing pattern for pivampicillin (fig 5).

Ciprofloxacin was regarded as an important advance in antimicrobial chemotherapy, and after its introduction in 1987 there was a substantial overall increase in its usage (fig 6).

In 1987 the cost of the 1.97 million prescriptions for anti-infective agents dispensed in Northern Ireland was $£ 5.78 \mathrm{~m}$, representing a rise of $10 \%$ since 1983 (fig 1). This compared favourably with the $33 \%$ rise in the cost of all prescriptions in Northern Ireland. The increase in costs of antimicrobials between 1985 and 1987 closely paralleled the rise in usage of the occasional compounds. Total annual prescription costs for individual agents were not available from the Central Services Agency. Nevertheless, by referring to standard ingredient prices (British National Formulary, ${ }^{13}$ Central Services Agency) analysis of the daily cost of normal adult treatment with common and occasional compounds in 1987 (table) showed the relatively high cost of the more recently introduced compounds such as amoxycillin-clavulanic acid, ciprofloxacin, and cefuroxime axetil compared with the common agents. The table also illustrates the relative cost of generic and proprietary preparations.

\section{Discussion}

Prescribing antibiotics in general practice hinges on the predictive value of the symptoms-sign complex. ${ }^{13}$ The diagnostic labels used in primary care often describe a wide range of illness and are not applied with such certainty as in hospital practice. ${ }^{14}$ In addition, 


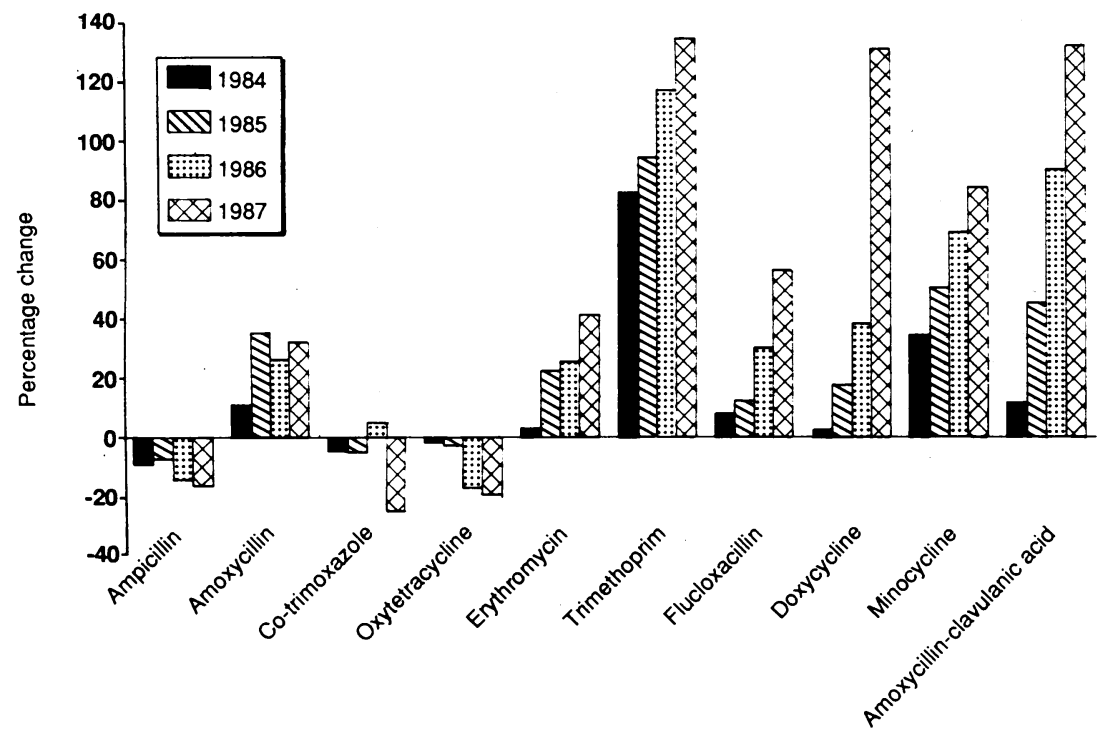

FIG 4-Percentage change in dosing units for some agents since 1983

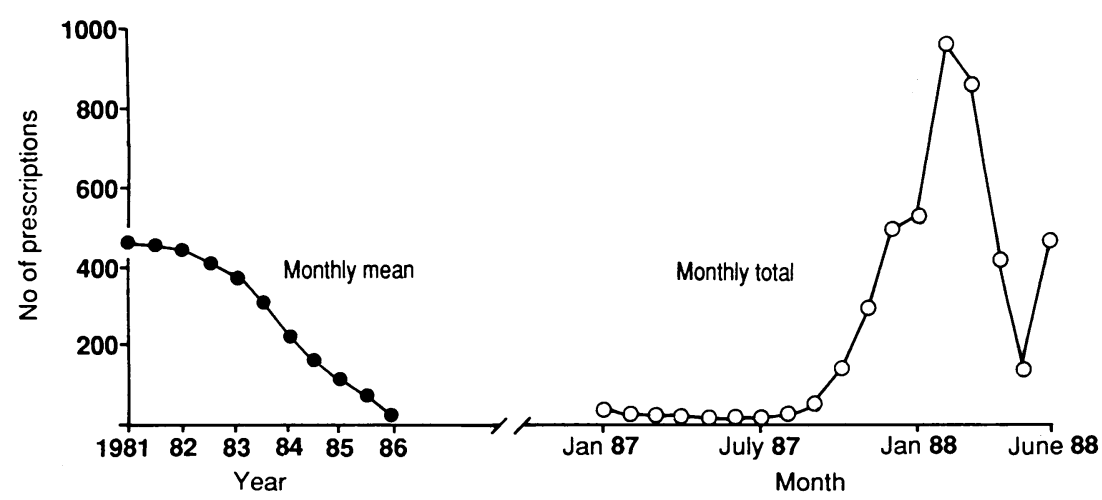

FIG 5-Mean monthly usage of pivampicillin a year between 1981 and 1986 and actual monthly usage between fanuary 1987 and fune 1988

FIG 6-Usage of ciprofloxacin between February 1987 and fune 1988

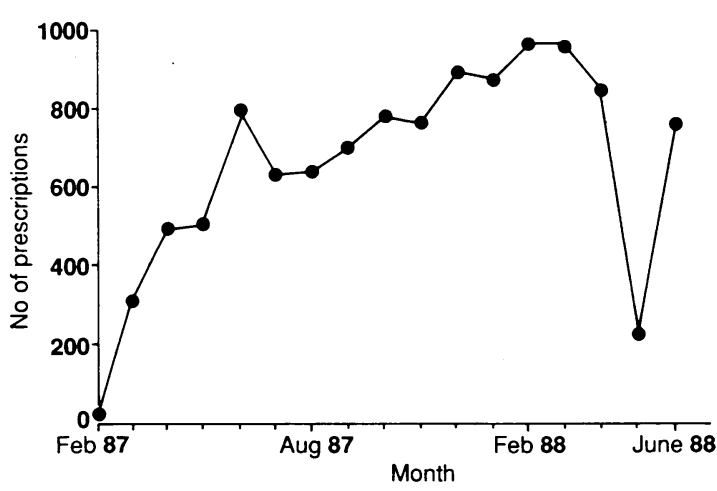

social and psychological history "significantly affects" whether the general practitioner prescribes antibiotics or not. ${ }^{15} 16$ Thus probability and the doctor-patient interaction may be the determining factors in whether an antibiotic will be prescribed and which it will be. The British National Formulary, though not fully confronting these dilemmas, advocates a conservative prescribing policy by, for example, urging that antibiotics should not be used in viral illness but when indicated should be chosen on a "best guess" basis. ${ }^{13}$

Our survey tends to confirm the application of the British National Formulary approach as the range of antimicrobials prescribed was fairly limited. In addition, within this group five agents accounted for $70 \%$ of the total volume of prescribing for all antimicrobial preparations.

A detailed analysis of the prescribing, however, highlights several important features. Firstly, there were a number of notable changes in the relative balance of the choice of agents prescribed. For example, the use of traditional tetracyclines declined in favour of the newer agents doxycycline and minocycline (fig 4). Similarly, within the common group of antimicrobials the decrease in the amount of ampicillin and cotrimoxazole prescribed was matched by an increase in prescribing of amoxycillin and trimethoprim. Though since 1985 the use of amoxycillin has exceeded that of ampicillin in terms of standard dosing units, ${ }^{17}$ the total amount of ampicillin prescribed was still greater than that of amoxycillin (fig 2). The main reasons for these trends are probably the potential benefits of amoxycillin over ampicillin in achieving better blood concentrations from equivalent doses ${ }^{18}$ and the better safety profile of trimethoprim over co-trimoxazole without any apparent compromise in clinical efficacy. ${ }^{19}$

Within the penicillins the prescribing of phenoxymethylpenicillin and the combination of ampicillin and flucloxacillin increased by $56 \%$ from 1983 to 1987 . More importantly, amoxycillin-clavulanic acid was prescribed $2 \cdot 3$ times more frequently in 1987 than 1983. Whether these observations suggest a shift in microbial sensitivities, aggressive marketing by the manufacturers, or a concerted effort on the part of prescribers to rationalise their choice of prescribing within the occasional group of drugs is not clear.

Secondly, though prescribers may try to limit the range of agents prescribed, ${ }^{20}$ it is important to note that those compounds which were prescribed occasionally in 1983 doubled their market position in the five years studied. This is a significant change as it represents a substantially different profile in prescribing which prompts the question of what factors influence such changes. Company marketing is undoubtedly a factor. For example, the sudden but dramatic increase in the prescribing of pivampicillin in 1987-8 after several years of declining use corresponded with concerted local promotion by the manufacturer (fig 5 ).

Not only is marketing itself an important factor, so is the way in which a product is promoted. For example, any incidence of resistance can be interpreted to promote the benefits of a particular compound. Though bacterial resistance is a problem in hospital, it is not widely observed in the community and should not be given undue emphasis in the decision to use new compounds..$^{21}$ Hence it may be argued that though ciprofloxacin, for example, deserves an important place in prescribing in hospital, its increased use in the community is unjustified. ${ }^{22}$ Therefore, rather than attempt to overcome or pre-empt resistance by prescribing yet another agent the objective should be to prevent resistance by limiting the amount of antibiotic prescriptions."

The third feature illustrated by the data is the cost implication of prescribing. Though the increase in prescribing costs for antimicrobials in Northern Ireland is modest $(10 \%)$ as compared with that for other therapeutic classes (33\%), a notable increase in prescribing costs for antimicrobials occurred in 1987 (fig 1). This was to be expected after the substantial increase in the use of the occasional antimicrobial group in that year (fig 4) and the generally higher cost of these agents (table). The importance of cost, however, becomes more apparent when viewed in an individual context. For example, each course of ciprofloxacin prescribed for a simple urinary tract infection would buy 11 courses of a cheaper alternative antibiotic, ampicillin. In 1987 the total usage of ciprofloxacin in Northern Ireland accounted for 7404 prescriptions (150 448 doses) at a total cost of $£ 112836$. Assuming that ampicillin could have been prescribed with equal effectiveness, the saving would have been $£ 103057$. Similarly for the treatment of acne, replacing doxycycline $(50 \mathrm{mg})$ and minocycline with oxytetracycline could have resulted in a saving of $£ 704626$.

Against this background the introduction of a general practice formulary, while allowing for a voluntary and 
systematic approach to antimicrobial prescribing, has several anticipated benefits. Firstly, it could focus prescribers' attention on a major aspect of drug use and thereby increase awareness of the clinical, social, behavioural, and economic issues. Secondly, it would be likely to contribute to a more informed prescribing base by providing evaluated information on different agents, their comparative properties, key indications, dosage schedules, adverse effects, and drug interaction profiles and cost. ${ }^{23}$ Thirdly, it could serve as a consensus for comparison whereby prescribers evaluate their own prescribing retrospectively when presented with prescribing feedback. Finally, it could provide a basis whereby a practitioner could set himself or herself targets relative to containing cost within specific clinical states.

Though our survey has disclosed reasonably conservative prescribing, there has been a distinct move towards prescribing a wider range of compounds coupled with an increase in the number of prescriptions and amounts prescribed. If not checked this trend is likely to continue and may well result in depriving the doctor of valuable drugs through the development of resistance. The cost implications are plainly significant, and doctors need to adopt a more questioning approach before including new products in their prescribing. ${ }^{24}$ There is little doubt that most clinicians want information, particularly about antibiotics. ${ }^{25}$

This information was obtained with the cooperation of the Department of Health and Mr R G McMullan and staff of the pharmaceutical branch of the Central Services Agency. The research project was funded by the Department of Health and Social Services, Northern Ireland.
Anonymous. Doctors, drugs, and the DHSS [Editorial]. Br Med 7 1984;289. $1397-8$.

2 Grant GB, Gregory DA, Van Zwanenberg TD. Development of a limited formulary for general practice. Lancet $1985 ; \mathrm{i}: 1030-2$.

3 Frazer A. The use of antibiotics in general practice. Aust Fam Physician 987;16:1264-71.

4 Hamilton-Miller JMT. Use and abuse of antibiotics. $\mathrm{Br} f \mathrm{Clin}$ Pharmacol 1984;18:469-74.

Maki DG, Schuna AA. A study of antimicrobial misuse in a university hospital. Am F Med Sci 1978;275:271-82.

6 Howie JGR, Bigg AR. Family trends in psychotropic and antibiotic prescribing in general practice. $\mathrm{Br}$ Med $\mathcal{f}$ 1980;280:836-8.

7 Gould IM. Control of antibiotic use in the United Kingdom. $\mathcal{I}$ Antimicrob Chemother 1988:22:395-7.

8 Williams JD. Antibiotic policy. Scand f Infect Dis 1986;49(suppl):175-81.

9 Wyatt TD, Ferguson WP, Wilson TS, McCormick E. Gentamicin resistan Staphylococcus aureus associated with the use of topical gentamicin. I Antimicrob Chemother 1977;3:213-7.

10 Wyatt TD, Ferguson WP, Wilson TS. Defence against bacterial drug resistance. BrMed f 1976;ii: 1503 .

11 Amyes S. Are GPs adding to the spread of resistance? MIMS $1989 \mathrm{Feb} 1: 33-4$

12 Anonymous. Antibiotics. Which? 1988 Nov: $510-1$.

3 Anonymous. Drugs used in the treatment of infections. In: Joint Formulary Committee. British national formulary. London: British Medical Association, Royal Pharmaceutical Society, 1987:186-211. (No 13.)

14 Howie JRG. Diagnosis - the Achilles heel. $\mathcal{f} R$ Coll Gen Pract 1972;22:310-5. 5 Howie JRG. Clinical judgment and antibiotic use in general practice. BrMed $\mathcal{f}$ 1975;ii:1061-4.

16 Howie JGR, Porter AMD, Forbes JF. Quality and the use of time in general practice; widening the discussion. $\mathrm{Br}$ Med $\mathrm{f}$ 1989;298: 1008-10.

17 Fox JS, Harron DWG. Trends in prescribing of anti-infective drugs in Northern Ireland. International Pharmacy fournal 1988;2:7-10.

18 Sutherland R, Elson S, Croydon EA. Amoxycillin: a new semi-synthetic penicillin. Br Med F 1972;iii:13-6.

19 Anonymous. Co-trimoxazole or just trimethoprim? Drug Ther Bull 1986;24: $17-9$.

20 Needham A, Brown M, Freeborn S. Introduction and audit of a general practice antibiotic formulary. $\mathcal{I} R$ Coll Gen Pract 1988;38:166-7.

21 Liss RH, Batchelor FR. Economic evaluation of antibiotic use and resistance -a perspective: report of Task Force 6. Rev Infect Dis 1987;9(suppl 3): 297-316S.

22 Pedler $\mathrm{S}$. A case for resisting the new antimicrobials. MIMS 1988 May 1:25-6.

23 Essex B. Toward more rational prescribing. Br Med f 1989;298:1052.

4 Anonymous. What to look for in a new antibiotic. Drug Ther Bull 1980;18: $65-7$

25 Morrow NC. Problem-orientated drug monographs developed for physicians in northern Ireland. Am f Hosp Pharm 1986;43:360-7.

(Accepted 21 December 1989)

\section{SOME NEW EDITIONS}

Aids to Undergraduate Surgery. 3rd edn. P M Mowschenson. ( $P p$ viii +163; 66.95 paperback.) Edinburgh: Churchill Livingstone, 1989. ISBN 0-443-04037-0.

Basics of Anesthesia. 2nd edn. R K Stoelting, R D Miller. (Pp x + $523 ;$ figs; $\{22.50$.) New York: Churchill Livingstone, 1989. ISBN $0-443-08571-4$

Boies Fundamentals of Otolaryngology: Textbook of Ear, Nose, and Throat Diseases. 6th edn. G L Adams, L R Boies Jr, P A Hilger. (Pp xii +560; figs; $£ 40$.) Philadelphia: Saunders, 1989. Distributed by Harcourt Brace Jovanovich. ISBN 0-7216-2802-8.

Cecil Essentials of Medicine. 2nd edn. T E Andreoli, C C J Carpenter, F Plum, L H Smith Jr. (Pp xvi+830; figs; £27.50 paperback.) Philadelphia: Saunders, 1989. Distributed by Harcourt Brace Jovanovich. ISBN 0-7216-2614-9.

Clinical Applications of Two-Dimensional Echocardiography and Cardiac Doppler. 2nd edn. A D Hagan, A N DeMaria. ( $\mathrm{Pp}$ xiii+556; figs; \{50.) Boston: Little Brown, 1989. ISBN 0-316-33784-6.

Clinical Practice of Transfusion Medicina. 2nd edn. Ed L D Petz, S N Swisher. (Pp xiii +790; figs; £75.) New York: Churchil Livingstone, 1989. ISBN 0-443-08548-X.

Clinical Procedures for Medical Assistants. 3rd edn. K Bonewit. Pp xv+606; figs and colour plates; £21.50.) Philadelphia Saunders, 1990. Distributed by Harcourt Brace Jovanovich. ISBN 0-7216-2895-8.

Collins and Lyne's Microbiological Methods. 6th edn. C H Collins, P M Lyne, J M Grange. (Pp x+409; figs; $£ 29.50$ paperback.) London: Butterworth Scientific, 1989. ISBN 0-407-00885-3. Diseases of the Gastrointestinal Tract and Liver. 2nd edn. D J C Shearman, N D C Finlayson, D C Carter. (Pp xiv + 1335; figs; \&95.) Edinburgh: Churchill Livingstone, 1989. ISBN 0-443-03110-X.

DRGS and Health Care: the Management of Case Mix. 2nd edn. Ed M Bardsley, J Coles, L Jenkins. (Pp x+230; figs; £16.95 paperback.) London: King Edward's Hospital Fund for London, 1989. ISBN 1-870551-96-6.

The Electromyographer's Handbook. 2nd edn. R K Sethi, L L Thompson. (Pp xii+199; figs; £21.50 paperback.) Boston: Little Brown, 1989. Distributed by Churchill Livingstone. ISBN 0-316-84187-0.

Equal Opportunities Task Force Occasional Paper. No 2 Revised edn. "Equal Opportunities Advisers in the NHS." King's Fund Equal Opportunities Task Force. (Pp 28. $£ 3.25$ paperback.) Fund Equal Opportunities Task Force. (Pp 28; 13.25 paperback. 1-870551-09-5.
General Anaesthesia 5th edn. Ed F J Nunn, J E Utting, B Brown Jr. (Pp xvi+1434; figs; £110.) London: Butterworth Scientific, 1989. ISBN 0-407-00693-1.

General Ophthalmology 1989. 12th edn. D Vaughan, T Asbury K F Tabbara. (Pp xx+460; figs; $\$ 26.65$ paperback.) Connecticut: Appleton and Lange, 1989. Distributed by Prentice-Hall International. ISBN 0-8385-3106-7.

Haimovici's Vascular Surgery: Principles and Techniques. 3r edn. H Haimovici, A D Callow, R G DePalma, et al. (Pp xxiv + 1103; figs; £124.95.) Connecticut: Appleton and Lange, 1989. Distributed by Prentice-Hall International. ISBN 0-8385-9382-8.

Kogan Page Careers Series. 4th edn. "Careers in Medicine, Dentistry and Mental Health." J Humphries. (Pp 96; 44.95 paperback.) London: Kogan Page, 1989. ISBN 1-85091-879-1.

Learning Medicine 1990: an Informal Guide to a Career in Medicine. 6th edn. P Richards. (Pp 98; figs; $£ 3.95$, overseas $£ 5.50$ Medicine, paperback, including postage, airmail overseas. BMA member $£ 3.45$, overseas $\mathfrak{5}$, including postage.) London: British Medical Association, 1989. In North America available from the American 19175, USA. ISBN 0-7279-0265-2.

Lecture Notes on Psychiatry. 7th edn. J Willis, J A Marks. (Pp xii + 123; figs; $\{8.95$ paperback.) Oxford: Blackwell Scientific, 1989. ISBN 0-632-02452-6.

Manual of Clinical Problems in Neurology: with Annotated Ke References. 2nd edn. Ed J P Mohr. (Pp xviii +360; 19.95 paperback.) Boston: Little Brown, 1989. Distributed by Churchil Livingstone, 1989. ISBN 0-316-57749-9.

A Manual of Systematic Eyelid Surgery. 2nd edn. J R O Collin (Pp xii+166; figs; $£ 18.50$ paperback.) Edinburgh: Churchill Livingstone, 1989. ISBN 0-443-04009-5.

National Boards Examination Review: for Part III. 2nd edn. 200 multiple-choice questions with explanatory answers, plus 15 patient management problems. B A Allen, J R Allen, P K C Chun, et al. ( $\mathrm{Pp}$ $x+275$; figs; $\{27.25$ paperback.) New York: Medical Examination Publishing Company, 1989. ISBN 0-444-01462-4.

Nomina Anatomica. 6th edn, together with Nomina Histologica 3rd edn, and Nomina Embryologica 3rd edn. Ed R Warwick,

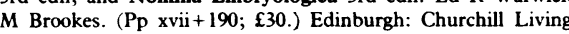
stone, 1989. ISBN 0-443-04085-0.

Ostlere and Bryce-Smith's Anaesthetics for Medical Students. 10th edn. T B Boulton, C E Blogg. (Pp x+271; figs; $£ 6.95$ paperback.) Edinburgh: Churchill Livingstone, 1989. ISBN 0-443-02821-4.

Oxford Handbook of Clinical Medicine. 2nd edn. R A Hope, J M Longmore, P A H Moss, A N Warrens.' (Pp xii+796; figs; f10.95 plastic cover) Oxford: Oxford University Press, 1989. ISBN 0-19-261735-4.
Penguin Nursing Revision Notes. Revised edition "General Medical Nursing." Advisory editor P A Downie. (Pp viii + 134; figs; £3.99 paperback.) London: Penguin, 1989. ISBN 0-14-077092-5.

Penguin Nursing Revision Notes. Revised edition "Orthopaedic Nursing." Advisory editor P A Downie. (Pp viii+113; figs; £3.99 paperback.) London: Penguin, 1989. ISBN 0-14-077094-1.

The Politics of the National Health Service. 2nd edn. R Klein. (Pp x +257; $\{7.95$ paperback.) London: Longman, 1989. ISBN 0-582-03131-1.

Practical Fracture Treatment. 2nd edn. R McRae. (Pp x+328; figs; 55.95 paperback.) Edinburgh: Churchill Livingstone, 1989. ISBN 0-443-04007-9.

Practical Immunology. 3rd edn. L Hudson, F C Hay. (Pp xx + 507; figs; $\{17.50$ paperback.) Oxford: Blackwell Scientific, 1989. ISBN 0-632-01491-1.

Psychiatric Dictionary. 6th edn. R J Campbell. (Pp xxiv +811; £35.) New York: Oxford University Press, 1989. ISBN 0-19-505293-5.

Review of Medical Physiology 1989. 14th edn. W F Ganong. (Pp xiv+673; figs; $£ 22.70$ paperback.) Connecticut: Appleton and Lange, 1989. Distributed by Prentice Hall International. ISBN 0-8385-8429-2.

The Role of Fats in Human Nutrition. 2nd edn. A J Vergroesen, $M$ Crawford. (Pp xviii +580; figs; £54.) London: Academic Press, 1989. Distributed by Harcourt Brace Jovanovich. ISBN 0-12-718051-6.

Structure of the Human Brain: a Photographic Atlas. 3rd edn. S J DeArmond. M M Fusco, M M Dewey. (Pp vi+202; figs; 115 paperback.) New York: Oxford University Press, 1989. ISBN 0-19-504357-X

Textbook of Pulmonary Diseases. 4th edn. G L Baum, E Wolinsky. (Pp xviii+893+index; figs; £125.) Boston: Little Brown, 1989. Distributed by Churchill Livingstone. ISBN 0-316-08388-7.

The Treatment and Prevention of Acute Diarnhoea: Practical Guidelines. 2nd edn. World Health Organisation. (Pp vi+49; figs; $\$ 8.80$ paperback.) Geneva: World Health Organisation, 1989. ISBN 92-4-154243-8.

Vascular Surgery. 3rd edn. Ed R B Rutherford. (Pp lvi+1768+ indexes; figs; ₹140 two volume set.) Philadelphia: Saunders, 1989. Distributed by Harcourt Brace Jovanovich. ISBN 0-7216-2065-5,

Vascular Surgical Techniques: an Atlas. 2nd edn. Ed R M Greenhalgh. (Pp xiv +433; figs; £75.) London: Saunders, 1989. Distributed by Harcourt Brace Jovanovich. ISBN 0-7020-1377-3.

Wills' Biochemical Basis of Medicine. 2nd edn. J H Thomas, B Gillham. (Pp xxii +590 ; figs; $£ 19.95$ paperback.) London: Wright, 1989. Distributed by Butterworth Scientific. ISBN 0-7236-0914-4. 